\title{
Connecting the world's risk and insurance communities: why research-based dialogue is more important than ever
}

\author{
Walter B. Kielholz ${ }^{1}$
}

Accepted: 24 February 2021 / Published online: 8 April 2021

(c) The Geneva Association 2021

\begin{abstract}
Almost half a century ago, The Geneva Association was founded as a 'club' of mostly European insurance CEOs. Over the decades, it has grown into a truly global organisation, with CEOs of non-European re/insurers now forming the majority of members. The organisation's recipe for success, however, has remained unchanged throughout the decades: the targeted creation of executive networks to facilitate the generation of relevant intellectual capital, in close collaboration with academia, aimed at giving the global insurance industry a credible voice vis-à-vis its key stakeholders.

The current and future insurance challenges and opportunities analysed in this paper illustrate the powerful case for The Geneva Association. Some of those developments seem truly unique and unprecedented, such as the shift from tangible to intangible assets and the Big Data-induced possibility of replacing risk pooling with personalised risk coverage. The concomitant intellectual, strategic, commercial and political issues facing the global insurance industry appear to be even more complex and global in nature than those that prevailed half a century ago.
\end{abstract}

\section{How it all started}

The Geneva Association's establishment in 1973 took place at an eventful time. The first 'oil shock' caused the price of crude oil to multiply, plunging the global economy into a severe crisis, with shrinking output, soaring inflation and rising unemployment. The shock was triggered by the Yom-Kippur War, after which the members of the Organization of Petroleum Exporting Countries (OPEC) proclaimed an embargo targeted at certain nations (Hamilton 2011).

This first major economic shock after the Second World War followed on the heels of the startling 'Limits to Growth' report, an investigation commissioned by

In memory of Orio Giarini.

Walter B. Kielholz

Walter_Kielholz@swissre.com

1 Swiss Re, Zurich, Switzerland 
the Club of Rome into the world's exponential economic and population growth, and its future limits set by finite natural resources (Meadows et al. 1972). This report, for the first time ever, sparked an intense global debate about the ecological and societal constraints to economic growth. It ultimately paved the way for the concept of sustainable development, which acknowledges the existence of major economic, societal and ecological trade-offs. Even prior to his role at The Geneva Association, Orio Giarini was closely associated with the Club of Rome and helped organise its first formal annual meeting in Bern in 1970.

Another important piece of context on the roots of The Geneva Association is the process of European integration. In 1973, Denmark, Ireland and the U.K. joined the European Union (EU), raising the number of Member States to nine. In the following two years, the last right-wing dictatorships in Europe came to an end with the overthrow of the Salazar regime in Portugal and the death of General Franco of Spain. On the economic and commercial level, the 1957 Treaty of Rome, which created the Common Market, also called for the liberalisation of financial services. Fulfilling this mandate, between 1964 and 1973, the European Council adopted a number of directives on banking and insurance, abolishing restrictions on the provision of cross-border services and commercial establishment abroad (EUR-Lex 2020).

When Orio Giarini took the helm at the newly established Geneva Association, Europe's insurance markets were characterised by widespread state ownership, especially in France and Italy - a legacy from the devastation wrought by the Great Depression, which forced governments to intervene on a larger scale in response to corporate defaults (Aganin and Volpin 2003). During the 1960s and 1970s, insurers started to worry about the prospect of an even larger public-sector footprint in their industry: the rapidly growing 'bread and butter' third-party motor liability business was heavily loss-making, mainly as a result of accelerating economic inflation and a subsequent increase in insurance claims. This trend fuelled calls for more state intervention (beyond imposing mandatory insurance requirements) and even nationalisation (Swiss Re 2020b).

In addition to state involvement, the largely domestic nature of business was a defining feature of insurance markets during this time. Only a handful of insurers had established international operations, mostly British companies expanding alongside the Empire (Wilkins 2009).

Against this backdrop, insurance executives felt that policymakers were largely ignorant about the essence and potential of private-sector insurance. It was generally considered a 'secondary' activity, also by the academic community (Giarini 2011). In order to address these perceptions through a dedicated platform for dialogue and research, The Geneva Association was officially formed on 27 February 1973 by a number of CEOs representing major European re/insurers. ${ }^{1}$ Raymond Barre, who

\footnotetext{
${ }_{1}$ Allianz, Münchener Rück, Aachener \& Münchener and Victoria for Germany; Commercial Union, Royal and Mercantile \& General for the U.K.; Erste Allgemeine for Austria; Royale Belge for Belgium; UAP, AGF, La Paternelle, Préservatrice and SAFR for France; Generali, RAS, Reale Mutua, INA and Fondiara for Italy; Nationale Nederlanden for the Netherlands; and Swiss Re for Switzerland (Giarini 2011).
} 
later became the Prime Minister of France, served as The Geneva Association's first President and Orio Giarini was named Secretary General.

\section{The first 25 years}

In the early stages of The Geneva Association, the organisation's focus was on formal and informal networking among CEO members, primarily elderly gentlemen cherishing a club-like atmosphere and the opportunity to exchange views on specific industry topics of general interest. The initial emphasis was placed on corporate risk management. During the 1970s, major toxic tort (e.g. asbestos) and environmental liabilities resulted in the first judicial decisions that radically extended the 'long tail' of affected insurance policies (Priest 1991). Businesses became more aware of the vulnerabilities arising from production techniques and the use of new products and materials. At the same time, corporate risk managers increasingly started to look at the totality of risks and the associated insurance contracts, which also included the evaluation of alternative approaches, such as self-insurance, through captive companies (Ward 2001) — much to the alarm of commercial insurers. With that in mind, Giarini initiated studies and surveys on a number of industrial vulnerabilities and risks, e.g. in the chemical sector, and later on risks linked to the use of computers (Loubergé 1981).

Giarini also realised that, in order to more effectively reach today's and tomorrow's decision-makers, it was strategically important to anchor insurance and risk issues more firmly in the academic sphere. Thus, The Geneva Papers on Risk and Insurance was launched-until today, the flagship publication of The Geneva Association. This journal presents papers intended to advance the scientific knowledge of risk management and insurance, but with a clear objective of stimulating dialogue between academic researchers, the insurance industry and its major stakeholders in public policy and other relevant areas. In addition, Giarini set up the European Group of Risk and Insurance Economists (EGRIE), a non-profit organisation dedicated to promoting research on risk and insurance. EGRIE organises scientific conferences and meetings, publishes research materials and fosters academic networks. It is now being recognised as one of the leading platforms in the field of insurance economics.

In the late 1970s and early 1980s, The Geneva Association underwent a profound change in its content strategy. The focus shifted to broader issues related to social vulnerability, such as the future of pension systems. A slowdown in growth was a global phenomenon during that time, coupled with increasing life expectancies and rising inflation. This confluence of factors fuelled debates about the sustainability of pension systems. In this context, Giarini promoted a more holistic assessment of all financial resources available to individuals and families: private savings, life insurance, personal property and real estate, and social welfare. By tearing down intellectual silos he aimed at putting insurers in a better position to fully understand their vital role in and contribution to old-age security. With Giarini's support and encouragement, the most influential comparison between private insurance and public and private welfare was published in France (Kessler et al. 1981). In this context, it is 
worth mentioning that Giarini was greatly inspired by and impressed with the Swiss retirement system and its strong reliance on compulsory occupational ('second pillar') as well as voluntary ('third pillar') pension savings.

Having contributed to the initial awareness of the delicate prospects of European-style welfare states, The Geneva Association then went on to outline potential responses to the challenges identified. Against this backdrop, the 'Four Pillars' project was launched in 1988, starting from the fact that life expectancies in virtually all countries were trending upwards. The Geneva Association's research was predicated on the assumption that longer lifespans could be viewed as a boon rather than a bane, adding 10-20 years of active life in a reasonably good state of physical and mental health. Thus, The Geneva Association advocated the establishment of a fourth pillar of retirement: a flexible extension of work life beyond minimum retirement age, mainly on a part-time basis, in order to supplement income from the three existing pillars (state pensions, occupational pensions and individual savings) (Giarini 1990). This pioneering work is testament to Giarini's admirable foresight and farsightedness.

When launching the 'Four Pillars' programme, Giarini may also have considered his personal belief in working beyond retirement age. As a matter of fact, he remained active and involved in risk and insurance matters long after he retired from The Geneva Association at the age of 64. Another example of Giarini's ability to link his personal life experience with relevant research topics was his artificial hip joint. This experience added further credibility to his pursuit of the topic of defective products and product recall. In the early 1990s, The Geneva Association conducted the first European survey ever on this topic (Giarini 2011), which, 10 years later, attracted a great deal of attention in Switzerland when Sulzer Medica got into severe trouble after it turned out that hip joints produced by the company were contaminated with traces of mineral oil (Olsen 2002). Having said this, Giarini also saw artificial hip joints in a bigger, more visionary context: the importance of continued physical mobility for mental well-being in old age.

\section{9-2003: presiding over The Geneva Association}

In 1998, the year after my appointment as CEO of Swiss Re, I first met with Orio Giarini at The Geneva Association's 25th General Assembly held in Dresden. In the following year, at the General Assembly in Rome, I accepted the nomination as the Association's new president, encouraged by Lukas Mühlemann, my predecessor at Swiss Re.

During the 1990s, deregulation, liberalisation and internationalisation were the top topics in insurance. In the EU insurance market, integration was given a boost through the single EU licence, the principle of Home Country Control and the abolition of substantive insurance supervision. The head office supervisor of an insurer was given responsibility for the financial aspects of regulation (solvency margin and technical reserves) not only for the home jurisdiction but also for branches in other EU countries and cross-border insurance business. In addition, approval requirements for rates and conditions (substantive supervision) were abolished (Boléat 
1995). Prior efforts towards liberalisation through the freedom of establishment and the freedom of services had remained largely ineffective due to the continued supremacy of local regulations.

In addition, the notoriously slow internationalisation of the insurance industry was expedited by the establishment of the World Trade Organization (WTO) and the first-time inclusion of services (such as insurance) on the liberalisation agenda. In the wake of these multilateral agreements, long-closed markets such as China and India began to open up (Branstetter and Lardy 2006).

Another prominent topic at the time was the battle over accounting standards for financial institutions. The International Accounting Standards Board (IASB) was pushing for new rules requiring a wide range of assets and liabilities to be shown at market value in financial statements. Critics argued that the adoption of the proposed rules would lead to unnecessary volatility in profits, potentially causing some insurers to avoid volatility by shunning stocks and corporate bonds. One of the most vocal opponents of the IASB's initiative was my fellow Geneva Association Board member, Claude Bébéar, chairman of AXA. He compared accounting rule makers to Iranian religious leaders ('super-super ayatollahs') (Norris 2003).

A less controversially debated top topic around the turn of the millennium was the emergence of risk-adjusted capital models. From the early 1990s, major regulatory jurisdictions either revised or started considering major revisions to their approach to solvency monitoring, with an emphasis on introducing risk-based capital (RBC) regulations. RBC regulatory systems for insurance were first introduced in Canada and the U.S. in 1992 and 1994, respectively. Japan and Australia followed suit in 1996 and 2001. Switzerland adopted the Swiss Solvency Test in 2006. In 2002, preparations for introducing the Solvency II RBC standards framework kicked off in the EU (Cummins and Phillips 2009), accelerated by the burst of the dotcom bubble, which spelled trouble for a number of European insurers, for example life insurers in Germany with a heavy stock market exposure of up to $25 \%$ of invested assets, considerably more than their U.S. counterparts (Schwarzbach et al. 2014).

On 11 September 2001 the issue of insurability was catapulted to the top of the industry's agenda. The terrorist attack on the World Trade Center in New York confronted insurers with events that they would have qualified ex ante as impossible, unrealistic or unthinkable. The use of passenger jets as flying bombs was such an event - and it turned out to be the most expensive insured loss up to this point. The Geneva Association responded with an authoritative and comprehensive analysis of this shock's short-, medium- and long-term implications (The Geneva Association 2002), also drawing on previous work on the limits to insurability (e.g. Holsboer 1995).

The rising frequency and severity of major natural disasters rounded off the eventful range of topics The Geneva Association dealt with at the turn of the millennium. This global debate, increasingly linked to the emerging challenge of climate change (Swiss Re 1994), was led by the reinsurance members of the Association, including some mid-sized companies. The 1990s had seen the two largest insured losses to this point, Hurricane Andrew in 1992 and the Northridge Earthquake in 1994, with total claims reaching about USD 20 billion for each event, raising questions about the long-term insurability of natural disaster risk (Kunreuther 1996). 
In summary, during the 1990s and early 2000s The Geneva Association significantly increased its engagement with global, rather than primarily European, issues. This shift was accompanied by a strongly improved geographic diversification of its CEO membership base, with a much broader footprint in the U.S. and Japan in particular.

In my term of office as Geneva Association President, I encouraged closer ties with the Institute of International Finance (IIF), the global association of the financial industry with more than 450 corporate members from more than 70 countries. Its mission was and still is well aligned with The Geneva Association's: to support the financial industry in the prudent management of risks; to develop sound industry practices; and to advocate for regulatory, financial and economic policies that foster global financial stability and sustainable economic growth. Serving as the IIF Vice Chairman since 2011, I remain convinced that this affiliation serves the global insurance industry well. It is important for insurers to have a voice in bodies which tend to be dominated by banks and have a proven track record in advocacy work.

\section{Taking stock: successes and failures of The Geneva Association}

Having observed and been engaged with The Geneva Association for more than two decades, I strongly believe that the relevance of the organisation is primarily towards its internal stakeholders, rather than external constituencies.

The institutionalised opportunity for each CEO member to establish personal relationships with peers around the world is invaluable. Since its inception, The Geneva Association has provided a unique platform to discuss industry issues of strategic relevance in a focused, in-depth and relatively intimate way. The thematic work of The Geneva Association Secretariat has always served as an important source of inspiration for the member CEOs and has in turn benefited from their strategic and commercial perspective. The 'social' capital generated at CEO level remains the (invisible) basis of The Geneva Association's reputation as a source of credible and authoritative intellectual capital.

Beyond the many intellectual achievements of The Geneva Association, the platform has also brought very tangible commercial benefits to some of its members. The development of personal relationships between industry leaders may have facilitated mergers and acquisitions in global insurance markets. Under Giarini's successor Patrick M. Liedtke, the membership base of The Geneva Association grew to more than 80 CEOs and its networking properties were further developed. In addition to the annual general meeting of CEO members, further dialogue forums were built for finance, risk, investment and economic research executives from the ranks of the member companies.

In addition to these 'internal' benefits, The Geneva Association had an important external impact in the academic field. Through numerous co-operations, already initiated under the aegis of Giarini, the ground was prepared for a much deeper integration of academic research and corporate strategy. In addition, it was possible to embed insurance content more strongly into academic curriculae, especially 
in emerging markets, e.g. through The Geneva Association's co-operation with the Asia-Pacific Risk and Insurance Association (APRIA).

What ultimately failed, however, were efforts in the wake of the Global Financial Crisis of 2008 to transform The Geneva Association into an advocacy organisation. Of course, the goal itself was understandable given the lack of awareness on the part of policymakers, legislators and regulators of the specifics of the insurance business, especially in the context of systemic risks to financial stability. Based on the targets put forward by the G20, preliminary considerations were given in 2009 to introducing macro-prudential supervision to the financial sector. This discussion pivoted around whether and to what extent systemic risks exist in financial services and how these risks can be addressed by supervision and regulation. Following the establishment of the Financial Stability Board (FSB) in April 2009, this discussion gathered steam. The re/insurance industry undertook great efforts to remind relevant stakeholders of the fact that the business model of insurance had never given rise to systemic risks to financial stability (The Geneva Association 2010).

The intended shift towards advocacy and lobbying failed for the following reasons, among others: firstly, there was no 'natural' interlocutor for The Geneva Association at the global level, apart from perhaps the International Association of Insurance Supervisors (IAIS), whose influence, however, is relatively limited. The situation is different in the banking sector, where the Bank for International Settlements (BIS), as the global organisation of national central banks, is an ideal interlocutor for the financial institutions organised under the umbrella of the IIF. Secondly, The Geneva Association lacked the experience, critical organisational mass and the budget, also in comparison to the IIF, to be able to carry out global advocacy and lobbying tasks effectively. Thirdly, it proved problematic to reconcile increased lobbying activities with The Geneva Association's historically grown role and credibility as a source of academically sound and widely respected analysis. The former did not gain the desired momentum, while the latter was in danger of being damaged. Finally, a fourth reason was the fact that The Geneva Association (with less than 80 CEO members from primarily large insurers) was perceived as not fully representative of the global insurance sector. The national and regional insurance associations, intellectually strengthened by The Geneva Association's research, seemed better suited to lobbying.

\section{The Geneva Association's relevance in today's business environment}

The Geneva Association's unique ability to pool 'social' and intellectual capital is as important today as it was then. Accelerated or even triggered by COVID-19, permanent changes to the global risk landscape are to be expected, which are most likely to be successfully managed on the basis of globally-shared insights, such as those generated by The Geneva Association.

At the political level, the trend towards fiercer great-power competition, most notably between China and the U.S., will further intensify. The pre-pandemic focus on trade disputes has already morphed into a full-blown technology rivalry, ranging from $5 \mathrm{G}$ technology, access to semiconductor technology and consumer apps. China 
and the U.S. will continue to diversify away from each other, which could result in a globally fragmented landscape of technology standards. This fragmentation will not only be more difficult to 'risk manage' but could also erode the economic benefits enabled by the Internet of Things and other technologies (Petri 2019; Deutsche Bank Research 2020).

Another key political trend for insurers to monitor is 'Big Government'. As 'spenders of last resort' (Swiss Re 2020a) the public sector has assumed an unprecedentedly active and massive role during the COVID-19 crisis. Policies adopted after the Global Financial Crisis in 2008, seen as radical at the time, now appear 'paltry' in comparison. Experience from the financial crisis suggests that temporary and unconventional emergency stimulus measures may well become permanent (Friedman 2014). This could develop into a threat to the global insurance industry. The potential perpetuation of 'Big Government' may well 'crowd-out' insurers as private-sector providers of safety nets and protection solutions.

At the commercial and economic level, COVID-19 is expected to hasten changes in how economies function, businesses are run, and risks are managed. Rather than a wholesale turning point, most experts believe that the pandemic will result in an acceleration of forces already under way, such as 'peak globalisation', the concentration of economic power in the hands of a few corporate behemoths and the digital penetration of ever more aspects of commercial and personal lives.

During the two decades preceding the Global Financial Crisis, trade volumes increased at around twice the rate of global GDP; since 2012, the rate of growth in trade volumes has barely kept pace with the economy at large. Foreign direct investments even fell (WTO 2020). Similar to cross-border trade flows and investments, the globalisation of supply chains had passed its peak even prior to the pandemic. The Thai floods and the Tohoku earthquake and tsunami in Japan in 2011, for example, highlighted the risks associated with complex, long, unwieldy and highly specialised supply chains (Haraguchi and Lall 2015; Todo et al. 2015) —and the challenges and limitations of managing such risks through contingent business interruption insurance.

More generally, the pandemic could have a lasting effect on how businesses manage the perennial trade-off between corporate efficiency and resilience. The fixation on efficiency and productivity is now being perceived as having damaged the capacity to prevent, deal with and bounce back from severe adversity. The corporate future, therefore, may see a rebalancing of efficiency and resiliency (Birkinshaw 2020). Accordingly, the role and value of risk management and insurance are likely to be seen from a different perspective going forward.

The pandemic has also hastened and amplified the digitisation of the corporate world as consumers rapidly switched from 'bricks-and-mortar' transactions to virtual work, education, shopping, entertainment and other traditionally in-person interactions (Deutsche Bank Research 2020). Insurers will have to respond accordingly, and much faster than they had expected, with customer preferences virtually changing overnight.

In addition, as a result of accelerated digitalisation, the economy is set to become more dominated by firms with the most advanced stock of intangible assets and the biggest repositories of data. The shift towards digital has further strengthened the 
competitive edge of the largest (technology) firms, which were in a superior position to accommodate the pandemic-induced surge in online demand (Rose 2020).

This shift has added further urgency to one of the most fundamental challenges facing the global insurance industry in the twenty-first century: how to insure intangible assets, i.e. intellectual capital such as data, IPs and reputation (Swiss Re 2018). As far as their risk transfer capabilities and expertise are concerned, most insurers appear to be stuck in the 'bricks-and-mortar' world, ignoring the changing way of economic value creation; in 1975, tangible assets such as plant, property, equipment and inventory constituted more than $80 \%$ of the total market value of the S\&P 500 index. By 2020 that share had fallen to about $10 \%$, while intangible assets accounted for the other $90 \%$ of the market's value (Ocean Tomo 2020).

Besides insuring intellectual capital, insurers need to respond to the emergence of advanced risk models and ever growing pools of real-time data, accelerated by the COVID-19-induced intensification of digital connectivity. Industry 4.0 and the use of algorithmic prediction in insurance are viewed by many as the beginning of a new era. They promise to personalise insurance policies and premiums on the basis of individual behaviour and risk characteristics. The revolutionary core idea is that the price of risk would no longer reflect the calculated uncertainty of a broad and deep pool of policyholders. In this context, insurers need to address the possibility that the ubiquitous availability of individual risk information could undermine the principles of risk-pooling, risk-spreading and risk mutualisation-the very foundations of insurance (Cevolini and Esposito 2020).

From a broader societal perspective, digital technology and connectivity open opportunities for 'building back better', on the basis of a quickened transformation towards more sustainable operating models (WEF 2020). However, a greater dependency on technology, as expedited by the pandemic, has conjured up increased cybersecurity risks and catapulted a breakdown of IT infrastructure and networks onto the list of top concerns for corporate risk experts (WEF 2020). Again, insurers need to respond and develop meaningful responses in order to maintain their relevance in the changing cyber risk landscape (Richter and Wilson 2020) and, at the same time, safeguard their solvency in the face of systemic risks such as a global internet outage or, as seen recently, a wave of business continuity losses due to nation-wide lockdown measures (The Geneva Association 2020). The latter is an instructive example of the need for insurers to proactively clarify with policymakers what is insurable and what is not in order to avoid the-ultimately costly-impression of passing the buck as soon as disaster strikes.

\section{Concluding remarks}

Almost half a century ago, The Geneva Association was founded as a 'club' of mostly European insurance CEOs. From the beginning, the networking idea was in the foreground, but with a clearly defined purpose: to explore and, where possible, offer answers to central questions of risk management in collaboration with the academic world. 
Over the decades, The Geneva Association has grown into a truly global organisation, with CEOs of non-European re/insurers now forming the majority of members. At the same time, the content spectrum of The Geneva Association broadened to include issues of overriding socio-economic relevance, e.g. the future of old-age provision and fundamental aspects of insurability.

The organisation's recipe for success, however, has remained the same throughout the decades: the targeted creation of networks at CEO and C-suite level to facilitate the generation of relevant intellectual capital and to give the global insurance industry a credible voice vis-à-vis its key stakeholders. In this context, Jean-Claude Trichet, former President of the European Central Bank (ECB) and former Governor of the Bank of France, spoke of The Geneva Association as "a very intelligent way of defending insurers' long-term interests" (Giarini 2011).

The current and future challenges and opportunities analysed in this paper illustrate the unabatedly powerful case for The Geneva Association. In times of widening geopolitical divides and creeping economic and technological fragmentation, The Geneva Association's unique global platform for dialogue and networking is more relevant and important than ever. Insurance CEOs, policymakers, regulators and leading academic researchers rely on this platform to effectively pool their commercial, political and intellectual capabilities, enabling the insurance industry to contribute to 'a better world' - as The Geneva Association aspires to do.

Of course, every era entails fundamental changes to the risk landscape, and most contemporaries tend to exaggerate the current challenges compared to those of the past. Nevertheless, some of the recent developments highlighted in this paper seem truly unique and unprecedented, such as the shift from tangible to intangible assets and the Big Data-induced possibility of replacing risk pooling with personalised risk coverage. The current intellectual, commercial and political issues facing the global insurance industry appear to be even more complex and global in nature than those that prevailed half a century ago. Maybe today Jean-Claude Trichet would be talking about The Geneva Association as "a very intelligent way of proactively anticipating and shaping the global insurance industry's business environment", with the ultimate goal of maintaining and augmenting the relevance of insurance in modern economies and societies.

Acknowledgements The author would like to thank Kai-Uwe Schanz, Deputy Managing Director of The Geneva Association, for his contributions to this article.

\section{References}

Aganin, A., and P. Volpin. 2003. History of corporate ownership in Italy. European Corporate Governance Institute Finance Working Paper No. 17/2003. SSRN: https://ssrn.com/abstract=391180 or https://doi.org/10.2139/ssrn.391180.

Birkinshaw, J. The new board room imperative: From agility to resilience. Forbes. 28 March 2020. https://www.forbes.com/sites/lbsbusinessstrategyreview/2020/03/28/the-new-boardroom-imper ative-from-agility-to-resilience/?sh=35d8ea238671.

Boléat, M. 1995. The European single insurance market. The Geneva Papers on Risk and InsuranceIssues and Practice 20: 45-56.

Branstetter, L., and N. Lardy. 2006. China's embrace of globalization. NBER Working Paper 12373. 
Cevolini, A., and E. Esposito. 2020. From pool to profile: social consequences of algorithmic prediction in insurance. Big Data \& Society 7 (2). https://doi.org/10.1177/2053951720939228.

Cummins, J.D., and R.D. Phillips. 2009. Capital adequacy and insurance risk-based capital systems. Journal of Insurance Regulation 28. National Association of Insurance Supervisors.

Deutsche Bank Research. 2020. Life after covid-19.

EUR-Lex. 2020. https://eur-lex.europa.eu/legal-content/EN/TXT/?uri=CELEX\%3A31961X1201.

Friedman, B. 2014. Has the financial crisis permanently changed the practice of monetary policy? National Bureau of Economic Research (NBER) Working Paper 20128.

Giarini, O. 1990. Introduction: the opportunities of the Four Pillars' strategy. The Geneva Papers on Risk and Insurance-Issues and Practice 15: 95-99.

Giarini, O. 2011. The history of The Geneva Association. https://www.genevaassociation.org/about-us/ history.

Hamilton, J. 2011. Historical oil shocks. In Routledge handbook of major events in economic history.

Haraguchi, M., and U. Lall. 2015. Flood risks and impacts: A case study of Thailand's floods in 2011 and research questions for supply chain decision making. International Journal of Disaster Risk Reduction 14 (3): 256-272.

Holsboer, J. 1995. Insurability and uninsurability: An introduction. The Geneva Papers on Risk and Insurance-Issues and Practice 20: 407-413.

Kessler, D., A. Masson, and D. Strauss-Kahn. 1981. Social security and saving: A tentative survey. The Geneva Papers on Risk and Insurance-Issues and Practice 6: 3-50.

Kunreuther, H. 1996. Mitigating disaster losses through insuranc". Journal of Risk and Uncertainty 12: $171-187$.

Loubergé, H. 1981. The management of research in risk and insurance at The Geneva Association. The Journal of Risk and Insurance 48: 309-321.

Meadows, D.H., D.L. Meadows, J. Randers, and W. Behrens III. 1972. The limits to growth: A report for the Club of Rome's project on the predicament of mankind. New York: Universe Books.

Norris, F. 2003. Showdown looms in Europe over proposals on accounting. New York Times. 11 July 2003.

Ocean Tomo. 2020. Intangible asset market value study.

Olsen, E. Sulzer offers \$1 billion settlement for defective implants. New York Times. 4 February 2002.

Petri, P.A. 2019. United States-China technological rivalry. Brandeis University and Brookings Institution Draft Paper. SSRN: https://ssrn.com/abstract=3441035 or https://doi.org/10.2139/ssrn.3441035.

Priest, G.L. 1991. The modern expansion of tort liability: Its sources, its effects, and its reform. The Journal of Economic Perspectives 5 (3): 31-50.

Richter, A., and T.C. Wilson. 2020. Covid-19: Implications for insurer risk management and the insurability of pandemic risk. The Geneva Risk and Insurance Review 45: 171-199.

Rose, N. 2020. Will competition be another covid-19 casualty? Brookings: The Hamilton Project.

Schwarzbach, C., F. Kunze, N. Rudschuck, and T. Windels. 2014. Stock investments for German life insurers in the current low interest environment: More homework to do. Zeitschrift für die gesamte Versicherungswissenschaft 103: 45-63.

Swiss Re. 1994. Global warming: Element of risk.

Swiss Re. 2018. Global economic and insurance outlook 2020. Sigma No. 5.

Swiss Re. 2020a. Rebuilding better. Sigma No. 2.

Swiss Re. 2020b. 1960s and 70s: Booming markets and ballooning losses in motor. https://www.swissre. com/institute/research/sigma-research/50years/60s-70s-booming-markets.html.

The Geneva Association. 2002. Insurance and September 11-one year after. ed. P. Liedtke and C. Courbage.

The Geneva Association. 2010. Systemic risk in insurance-an analysis of insurance and financial stability.

The Geneva Association. 2020. The insurability of pandemic risk. Author: Kai-Uwe Schanz. October.

Todo, Y., K. Nakajima, and P. Matous. 2015. How do supply chain networks affect the resilience of firms to natural disasters? Evidence from the Great East Japan Earthquake. Journal of Regional Science 55 (2): 209-229.

Ward, S. 2001. Exploring the role of the corporate risk manager. Risk Management 3 (1): 7-25.

WEF. 2020. COVID-19 risks outlook: A preliminary mapping and its implications.

Wilkins, M. 2009. Multinational enterprise in insurance: an historical overview. Business History 51 (3): 334-363.

WTO. 2020. World trade statistical review 2020. 
Publisher's Note Springer Nature remains neutral with regard to jurisdictional claims in published maps and institutional affiliations.

\section{About the author}

Walter B. Kielholz has been Chairman of the Board of Directors of Swiss Re since 2009 and was Vice Chairman from 2003 to 2009. He joined Swiss Re in 1989, became an Executive Board Member in 1993 and was Chief Executive Officer from 1997 to 2002. He was also a member of the Board of Directors of Credit Suisse Group Ltd from 1999 to 2014 and served as Chairman from 2003 to 2009. In addition, Walter B. Kielholz serves as Vice Chairman of the Institute of International Finance. He was President of The Geneva Association from 1999-2003. 